\title{
BIOCHEMICAL EFFECTS OF COMBINED ACTION OF $\gamma$-IRRADIATION AND PACLITAXEL ON ANAPLASTIC THYROID CANCER CELLS
}

\author{
V. M. PUSHKAREV, O. I. KOVZUN, V. V. PUSHKAREV, M. D. TRONKO \\ State Institution «V. P. Komisarenko Institute of Endocrinology \& Metabolism», \\ National Academy of Medical Sciences of Ukraine, Kyiv; \\ e-mail: pushkarev.vm@gmail.com
}

\begin{abstract}
The aim of the paper was to describe the biochemical effects of Paclitaxel (Ptx), $\gamma$-irradiation (IR) and their combination in undifferentiated thyroid cancer cells (ATC). IR activated common DNA damage-induced signaling and manifested certain mitogenic effect by inactivation of retinoblastoma protein ( $p R b)$. There was clear antagonism between Ptx and IR relative to cell cycle regulators - tumor suppressor p53, $p R b, C H K 2$ and $c$-Abl as well as proapoptotic Bax expression, but combined action of both agents enhanced caspase-3 and, especially, caspase-8 activation. The Ptx at low (1-25 nM) concentrations caused noticeable radioprotective effect.

Thus, in ATC cells the ionizing radiation and Ptx exhibited competitive effects upon phosphorylation of cell cycle controllers: $553, p R b, C H K 2, c A b l$ and expression of Bax. At the same time, the combined effect of radiation and Ptx enhanced antiapoptotic Bcl-2 phosphorylation, caspases activation and survivin expression. The net effect of these events during the first 48-72 h of cells incubation can be considered as antiapoptotic - Ptx attenuated cytotoxic effect of IR.
\end{abstract}

Key words: paclitaxel, ionizing radiation, thyroid cancer, apoptosis, cell cycle.

$\mathrm{P}$ aclitaxel (Ptx) is one of the most effective anticancer drugs, which has been used to treat certain types of malignant tumors, including cancer of lung, breast, bladder, ovary, head and neck, and melanoma [1, 2]. Previously, we have shown the combined effect of Ptx and ionizing radiation (IR) in vivo in one of the most aggressive human tumors, anaplastic thyroid cancer (ATC) [3]. IR enhanced the effect of Ptx, and after 20 days of treatment tumors in mice disappeared. It seems that a combination of chemotherapy and DNA-damaging agents may be effective for ATC treatment. In this study, we attempted to elucidate the biochemical mechanisms of combined action of Ptx and IR in ATC cells in vitro.

\section{Materials and Methods}

Cell culture. Human ATC cell lines ARO (initially assumed to be anaplastic thyroid carcinoma cell line but recently reclassified into colon carcinoma) and FRO were initially provided by J. A. Fagin (University of Cincinnati College of Medicine, Cincinnati, OH, USA). ATC cell line KTC-2 (the basic line in our study with wtTP53) was established at Kawasaki Medical School (Okayama, Japan).

Throughout all experiments cancer cell lines were grown in RPMI 1640 supplemented with 5\% fetal bovine serum (FBS) and penicillin/strepto- mycin $(100 \mathrm{U} / \mathrm{ml} / 100 \mu \mathrm{g} / \mathrm{ml}$ ) (all reagents were from Invitrogen Life Technologies, Paisley, UK) in a $5 \% \mathrm{CO}_{2}$ humidified atmosphere at $37{ }^{\circ} \mathrm{C}$. After $2 \mathrm{~d}$ incubation, when the culture reached about $80 \%$ confluence, cells were washed twice with PBS (pH 7.4) at $37{ }^{\circ} \mathrm{C}$, and a fresh medium was added to each dish. Cells were incubated for additional $24 \mathrm{~h}$, exposed to the drug dissolved in DMSO (equal amount of DMSO was added to control samples) as described below, and then collected at different time intervals.

JNK inhibitor SP600125, (Calbiochem, USA) dissolved in DMSO was added to the medium at final concentration $5 \mu \mathrm{M} 1 \mathrm{~h}$ prior to Ptx.

Clonogenic assay. Clonogenic assay was performed as described elsewhere [4]. Briefly, cells were seeded at 500 cells per $10-\mathrm{cm}$ dish. Twentyfour hours later, fresh medium with Ptx was added. After exposure to the drug for $24 \mathrm{~h}$, the medium was changed and cells were grown for 2 weeks. Giemsa-stained cell colonies were counted.

Cell survival assay. Cultures were established in the 96-well flat-bottom microtiter plates in RPMI 1640 containing 5\% FBS. Cell suspensions (100 $\mu 1,1000$ cells/well) were added to each well and incubated for $24 \mathrm{~h}$ before treatment. Ptx (Wako Chemicals, Japan), dissolved in DMSO was added to each well at varying concentrations, six wells for each concentration. DMSO only was added to 
the control cells. After incubation, a water-soluble tetrazolium salt-based assay (WST) was performed as follows: $11 \mu \mathrm{l}$ of the cell counting kit solution (CCK-8, Dojin, Japan) was added to each well and incubated for $1 \mathrm{~h}$ at $37^{\circ} \mathrm{C}$. OD was read at $450 \mathrm{~nm}$ in a microplate reader.

Preparation of cell extracts. Adherent cells were washed twice with ice-cold PBS supplemented with sodium pyrophosphate and orthovanadate, scraped with a rubber policeman, collected in $1 \mathrm{ml}$ of PBS, and centrifuged for $3 \mathrm{~min}$ at $1000 \mathrm{rpm}$ at $4{ }^{\circ} \mathrm{C}$. The pellet was then resuspended in $200 \mu$ of the lysis buffer (Cell Signaling Technology) containing a cocktail of protease and phosphatase inhibitors. After $15 \mathrm{~min}$ on ice lysates were centrifuged for $15 \mathrm{~min}$ at $15000 \mathrm{~g}$ and stored at $-80{ }^{\circ} \mathrm{C}$ until use. Protein concentration was determined with bicinchoninic acid assay reagent kit (Sigma, USA) according to manufacturer's protocol.

Western blotting. Total cell lysates were boiled in the sample buffer $(100 \mathrm{mM}$ Tris- $\mathrm{HCl}, \mathrm{pH} 6.8$, $4 \%$ sodium dodecyl sulfate, $0.2 \%$ bromophenol blue, $20 \%$ glycerol, $10 \%$ dithiothreitol) and separated by SDS-PAGE 7.5-15\% gradient gels. The homogeneous 8 and $15 \%$ gels were used when better separation of high- and low-molecular-weight proteins, respectively, was needed. Forty micrograms of protein were applied per each lane. Proteins were transferred onto $0.2-\mu \mathrm{m}$ nitrocellulose membranes (Millipore Corp., USA) by semidry blotting. The membranes were blocked with Trisbuffered saline $/ 0.1 \%$ Tween 20 (pH 7.6) containing $5 \%$ nonfat dry milk or 5\% BSA and incubated with appropriate primary antibodies $(\mathrm{Ab})$ at $4{ }^{\circ} \mathrm{C}$ overnight. Polyclonal $\mathrm{Ab}$ for phosphoforms of $\mathrm{c}-\mathrm{Abl}$ (Thr735), Bcl-2 (Ser70), CHK2 (Thr68), p53 (Ser15), pRb (Ser807/811), MKK4 (Thr261) and for cleaved caspase-3 (Asp175), PARP (poly (ADP-ribose) polymerase); monoclonal $\mathrm{Ab}$ for cleaved caspase-8 (Asp384), survivin, $\beta$-actin were form Cell Signaling Technology Beverly, USA. Bax mAb were from Santa Cruz Biotechnology, USA). After washing three times with Tris-buffered saline/ $0.1 \%$ Tween 20 ( $\mathrm{pH} \mathrm{7.6),} \mathrm{the} \mathrm{blots} \mathrm{were} \mathrm{incubated} \mathrm{with}$ horseradish peroxidase-conjugated species-specific secondary antibody (Cell Signaling Technology) for $1 \mathrm{~h}$ at room temperature and then again washed three times. Complexes were visualized using the ECL reagents (Amersham, USA). Quantification of Western blotting results was performed with the GelPro software using integrated optical density (IOD) and maximal optical density (maxOD) parameters.

Cell irradiation. For the $\gamma$-irradiation, cells were exposed to a single dose of 0.5-20 Gy (Pony PS-3100SB, radiation source ${ }^{137} \mathrm{Cs}, 0.662 \mathrm{MeV}$, $1 \mathrm{~Gy} / \mathrm{min})$ next day after Ptx treatment.
Statistical analysis. All data were expressed as a mean \pm SD or mean \pm SE. Differences between groups were examined for statistical significance using Student's independent and paired test. $P<0.05$ denoted the presence of a statistically significant difference. The regression analysis was used for cell survival study of combined effects of Ptx and IR.

\section{Results}

\section{Effects of low and high doses of radiation and} Ptx on ATC cells in vitro.

Study of the IR action on the cell survival showed that high (5-20 Gy) doses of radiation actually had almost no evident effect in the first $24 \mathrm{~h}$ after irradiation (Fig. 1, A.1). A significantly lower cell survival occurred only at a dose of $20 \mathrm{~Gy}$. In 48 and $72 \mathrm{~h}$ after irradiation the dose-dependent decrease in cell survival was observed. The effect of IR on cell survival was significant starting with a dose of $5 \mathrm{~Gy}$. It is noteworthy that in the first 24 hours low doses of radiation - 0.5-2 Gy appeared to be more effective than higher doses (Fig. 1, B). Anaplastic cancer cell line KTC-2 was more sensitive to radiation exposure, possibly due to the presence of wild-type TP53, which is inactive in ARO cell line.

The Ptx effectively induced cell death (Fig. 1, $C)$. After $24 \mathrm{~h}$ of incubation with the drug, the number of live cells decreased by half (Fig. 1, C.1), dropped to $30 \%$ of control in $48 \mathrm{~h}$, and to $20 \%$ in 72 h (Fig. 1, C.2, 1, C.3). The effect of Ptx on cell survival was significant beginning from $5 \mathrm{nM}$ of the drug. It should be noted that relatively low Ptx concentrations appeared to be effective with no further decrease in cell survival starting from $10 \mathrm{nM}$. These results may have some practical importance, because clinically significant concentrations of Ptx are considered between 5 and $30 \mu \mathrm{M}$ $[5,6]$.

Clonogenic assay of ATC cells after exposure to $\gamma$-rays showed that at doses starting from $10 \mathrm{~Gy}$ colonies actually did not form (Fig. 1, D).

Study of combined action of Ptx and IR on cell survival showed that the final effect was dependent on Ptx concentration. Data obtained indicate that Ptx attenuated the IR effect at 1 and $25 \mathrm{nM}$ of Ptx (Fig. 1, E, 1, F). According to regression analysis the effect of IR is significant for control curve $(\mathrm{F}=20.3 ; P=0.05)$ and $\mathrm{Ptx}$ concentration $25 \mathrm{nM}(\mathrm{F}=222.1 ; P=0.004)$ for $48 \mathrm{~h}$ after irradiation. The effect of IR is significant for control curve $(\mathrm{F}=34.5 ; P=0.03)$, at Ptx concentration $1 \mathrm{nM}(\mathrm{F}=243.6 ; P=0.004)$ and $25 \mathrm{nM}(\mathrm{F}=137.4 ; P=0.007)$; the slope of curves: $-2.42 \pm 0.41$ for control curve compared to 

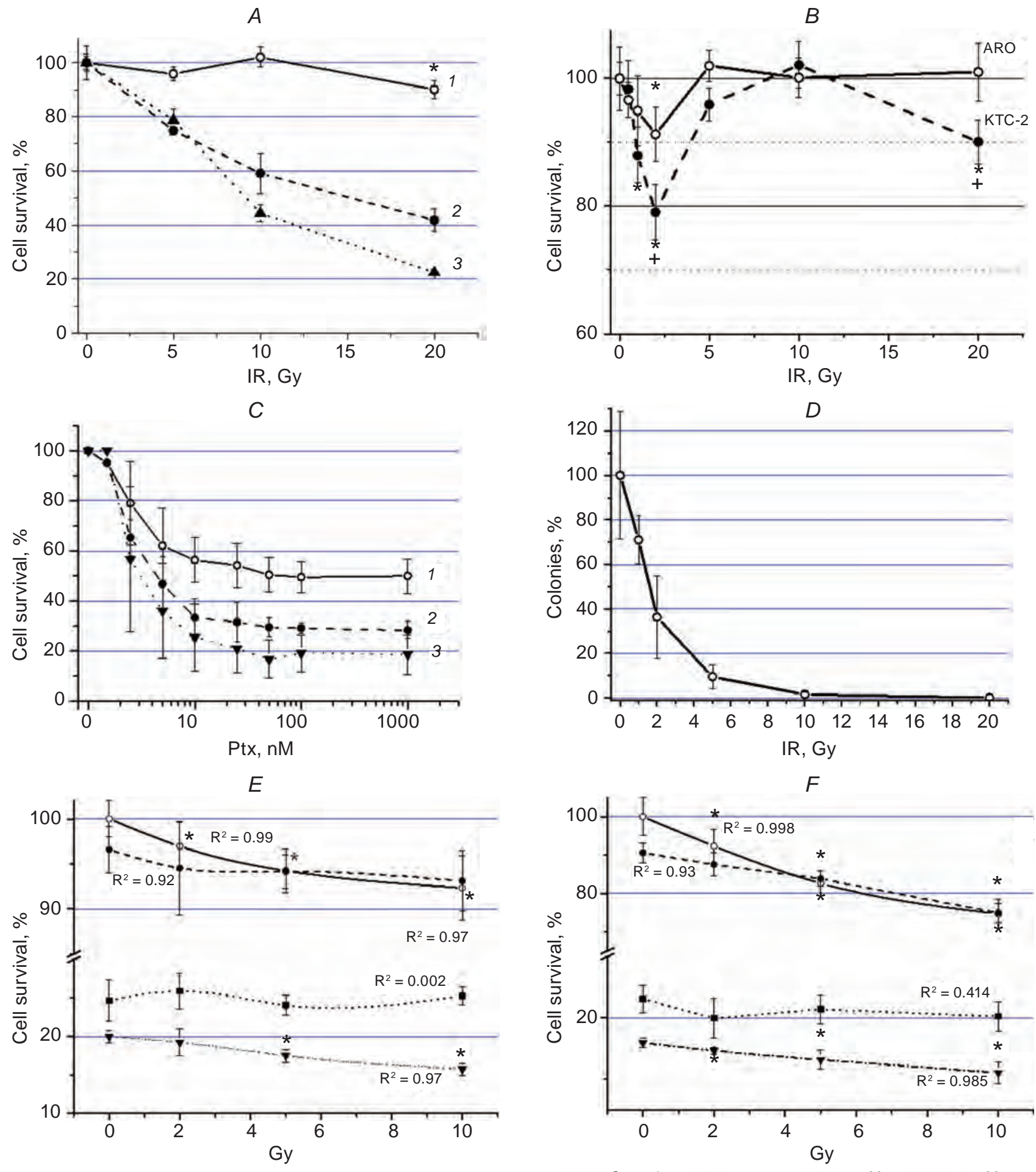

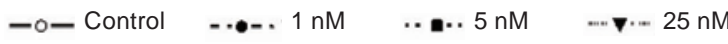

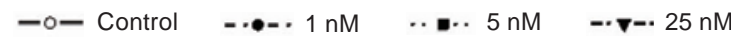

Fig. 1. Effect of Ptx and $\gamma$-irradiation on ATC cell viability and clonogenicity. A - Effect of high (5-20 Gy) IR doses on KTC-2 cells viability. 1, 2, 3-24 h, 48 h, $72 \mathrm{~h}$ of incubation following cells irradiation. $* P<0.05$ vs. control (O Gy), $M \pm S E(n=6)$. B - Comparison of high and low IR doses effect on cell viability in $24 \mathrm{~h}$ after irradiation. * $P<0.05$ vs. control $(0 \mathrm{~Gy})$; + differences between survival of ARO and KTC-2 cells are significant, $P<0.05, M \pm S D(n=6)$. C - Ptx cytotoxicity (ARO). 1, 2, $3-24 \mathrm{~h}, 48 \mathrm{~h}, 72 \mathrm{~h}$ of incubation with the drug, respectively. $M \pm S D(n=6)$. D - Clonogenic assay of irradiated FRO cells. $M \pm S D(n=3)$. $E, F-$ Effect of combined action of IR and Ptx on ARO cells survival. $E-48 h$ and $F-72 h$ of incubation following cells irradiation. $M \pm S D(n=6)$. * Difference between irradiated and control cells is significant, $P<0.05$ (paired $t$-test) 
$1.56 \pm 0.10$ and $0.50 \pm 0.04$ for Ptx concentration of $1 \mathrm{nM}$ and $25 \mathrm{nM}$ respectively for $72 \mathrm{~h}$ after irradiation.

At $5 \mathrm{nM}$ of Ptx, according to results of regression analysis, the cytotoxic effect of IR was insignificant. Thus it may be noted that at this concentration Ptx exhibits radioprotective effect (Fig. 1, E, 1, F).

The only Ptx concentration where we observed attenuated but stable IR effect was $25 \mathrm{nM}$ of the drug, and we used it for further analysis.

2. Expression and activation of proapoptotic and antiapoptotic factors in ATC cells on exposure to $I R$ and Ptx action.

The combined effects of IR and Ptx were studied at $5 \mathrm{~Gy}$, used in our experiments on animals [3] and $25 \mathrm{nM}$ of Ptx, where the maximum of apoptosis was observed in ATC cells [7], and which could be clinically relevant. According to Fig. 1, $E$ and $1, F$ data, the combined effects of IR and Ptx on cell viability in 48 and $72 \mathrm{~h}$ of incubation in such setting were significant $(P=0.0011$ and $P=0.0023$, respectively).

Both proapoptotic and antiapoptotic events under the joint action of IR and Ptx were observed. It was shown that $\gamma$-irradiation and Ptx essentially increased the expression of proapoptotic protein Bax (Fig. 2, 3). However, both agents used in combination seemed to reduce Bax content in the cells in comparison with the action effects of Ptx and IR as single agents. In addition, the enhanced expression of apoptosis inhibitor survivin under combined action of Ptx and IR was observed (Fig. 2, 3 ). Both Ptx and radiation alone significantly increase its expression, which is further enhanced in the presence of both agents. The decrease of Bax and the increase of survivin expression may indicate the attenuation of apoptotic process in tumor cells.

To test this possibility, the caspases activation was studied (Fig. 2, 3). IR did not activate caspase-3, and caspase-8, while Ptx activated caspase- 8 and, especially, the main effector caspase-3. A combination of Ptx and IR trended to increase activation of both caspases. A possible explanation for the contradiction between the decrease of Bax expression and increase of caspases activation is enhanced phosphorylation of antiapoptotic protein Bcl-2 under the combined action of Ptx and IR compared with phosphorylation of this protein in the case of each particular agent action (Fig. 2, 3).

A probable signaling pathway that mediates the apoptotic effects of Ptx and IR in ATC and other tumor cells is JNK cascade [7, 8]. This conclusion is supported by activation of MKK4 - protein kinase upstream to JNK (Fig. 2, 3). Another proof is provided by the experiment with JNK inhibitor - SP600125 (Fig. 4). It can be seen that IR itself does not essentially activate apoptotic mechanisms. There was no activation of caspase-3 and certain PARP cleavage. The effect of Ptx was noticeably stronger. The amount of activated caspase increased significantly and that of intact PARP decreased more than 20 times. This effect was almost entirely abolished in the presence of JNK inhibitor (Fig. 4), indicating the participation of this protein kinase in Ptx-dependent apoptosis.

3. Effects of Ptx and IR upon cell cycle regulatory mechanisms.

Since both Ptx and IR affect the cell cycle, it was of interest to determine the status of main regulators of the cell cycle upon the action of these agents, both individually and in combination.

The exposure of anaplastic cancer cells KTC-2 to $\gamma$-rays at a dose of 5 Gy markedly increased the phosphorylation on serine 15 of one of the key protein that controls the cell cycle tumor suppressor p53 (Fig. 5, A, 1). The phosphorylation leads to attenuation of its interaction with main negative regulator - oncoprotein Mdm2 [9]. This in turn allows p53 to avoid ubiquitination and subsequent proteasomal degradation and thus result in its accumulation in the nucleus and further transactivation of genes whose products may, depending on the strength of stress, arrest the cell cycle, initiate DNA repair, senescence or apoptosis [9]. Ptx at $25 \mathrm{nM}$ concentration, which induced the classical apoptosis in ATC cells [7], also increased the phosphorylation of p53 in the KTC-2 cells, but to a lesser extent, compared with IR. It should be stressed that in the presence of Ptx, IRdependent phosphorylation of p53 was significantly decreased (Fig. 5, $A, 1 ; 5, B$ ). One of the possible consequences of the p53 accumulation is transactivation of the genes whose products initiate apoptosis, particularly of proapoptotic protein Bax gene, which is one of the key factors in the mitochondrial pathway of apoptosis [10]. It is shown on Figs. 2, 3 and 4 that the expression of Bax as well as the phosphorylation of p53 increased after the irradiation of cells and in the presence of Ptx. However, the combined effect of IR and Ptx resulted in inhibition of $\mathrm{p} 53$ phosphorylation and Bax expression compared both with radiation exposure and the effect of Ptx separately. The same pattern of IR and Ptx actions is characteristic of phosphorylation of non-receptor tyrosine kinase c-Abl (Fig. 5, $A, 2$ ), which stimulates the accumulation of active p53 due to its stabilization [11, 12] and participates in Ptx-dependent processes: apoptosis induction, cell cycle arrest at G2/M phase [13]. The combined action of IR and Ptx almost completely abolishes the 


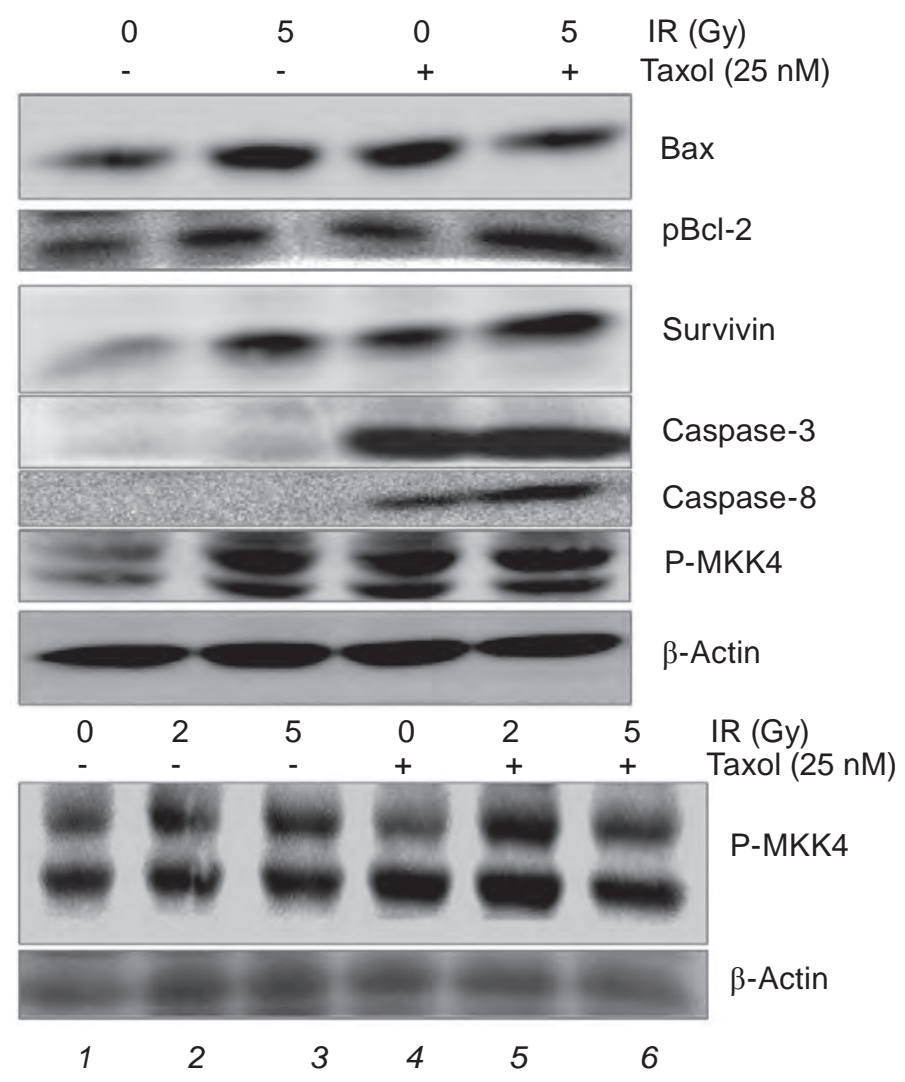

Fig. 2. Effects of Ptx, IR and combined effect of IR + Ptx on activation and expression of proteins involved in apoptosis. The activated (cleaved) forms of caspase-3 (p17/p19) and caspase-8 (p10) were detected

tyrosine kinase phosphorylation at Thr735 (Fig. 5, $A, 2)$.

It is known that ATM (ataxia telangiectasia mutated) kinase and checkpoint kinase 2 (CHK2) mediate effects of $\gamma$-irradiation on p53 activation [9]. Ptx and especially IR activate the CHK2 (Fig. 5, $A, 3$ ). In the presence of both agents, as in the case of p53, Bax and c-Abl, CHK2 phosphorylation and thus activation, were significantly decreased as compared to IR effect (Fig. 5, $A, 3$ ).

The action of IR caused inactivation of another tumor suppressor - retinoblastoma protein (pRb) (Fig. 5, A, 4, 5; 5, B), which occurred through cascade phosphorylation of $\mathrm{pRb}$ by cyclin/ $\mathrm{CDK}$ complexes and in turn resulted in the release of E2F family of transcription factors [14, 15]. The joint effect of both agents led to a significant attenuation of IR effect (Fig. 5, $A, 4,5 ; 5, B$ ). Thereby, IR by itself manifested the mitogenic effect, stimulating the cell cycle transition at the G1/S phase and initiation of DNA synthesis. A detailed analysis of mitogenic properties of Ptx was made previously [16].

\section{Discussion}

It was shown that Ptx activated caspase-9 in ATC cells [7, 17], indicating the induction of mitochondrial pathway of apoptosis. It is believed that this is the main mechanism of apoptosis induction, more important than the pathway through death receptors and caspase- 8 activation, the latter being realized only in some ATC cell lines [7]. The decrease of Bax expression upon exposure to IR and Ptx seems to be inconsistent with activation of caspases. A possible explanation for this contradiction is enhanced phosphorylation of antiapoptotic protein Bcl-2 upon the combined action of Ptx and IR compared with phosphorylation of this protein induced by each particular agent (Fig. 2, 2). The Bcl-2 oncoprotein is an inhibitor of apoptosis and often is overexpressed in malignant cells [18, 19]. Phosphorylation of Bcl-2 protein leads to inhibition of its protective, antiapoptotic properties [20]. Phosphorylated Bcl-2 also may degrade in proteasomes [21], as evidenced by decreasing amounts of this protein in ATC cells exposed to Ptx [7]. 

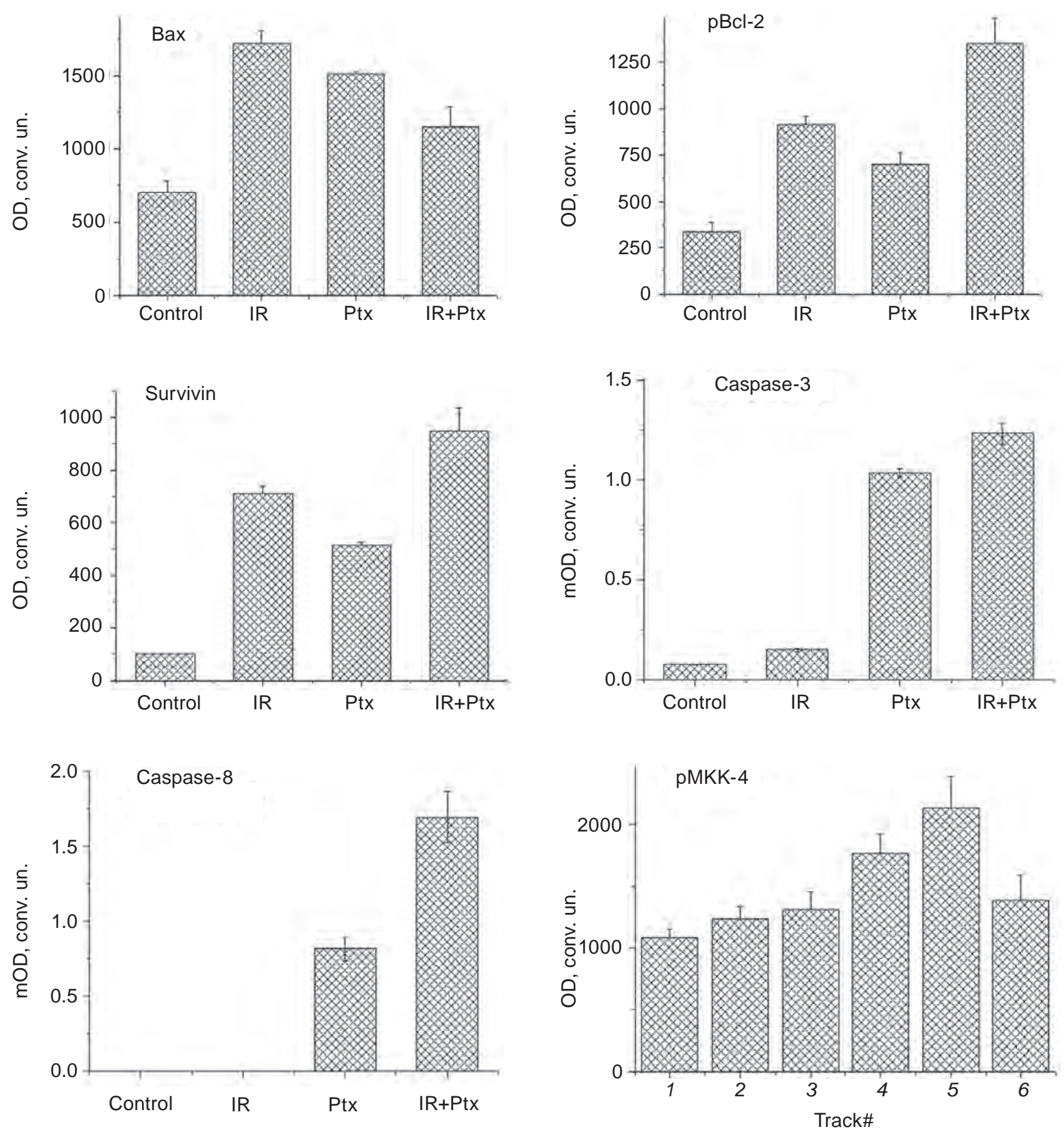

Fig. 3. Quantification of Western blotting results (Fig. 2). Y-OD in conventional units. 1-7 ARO cell line, 8, $9-K T C-2$ cells. Data are mean of $4 O D$ measurements of one blot by scanning software $\pm S E$ value (error of scanning). The maximum OD parameter was used when scanning of caspases bands. Track \# of pMKK4 scanogram corresponds to tracks on Fig. 2

One can assume that, together with inhibition of Bcl-2 function, proapoptotic proteins other than Bax such as Bad, Bak and particularly (considering the fact of caspase-8 activation), tBid could be involved in the initiation of apoptotic process in mitochondria under combined action of Ptx and IR.
The importance of $\mathrm{Bcl}-2$ for IR-induced apoptosis was confirmed by the data that Bcl-2 antisense oligonucleotide enhanced the activation of caspase-3 and caspase-7 in prostate cancer cell lines thus increasing their sensitivity to IR [22]. Interestingly, p53 was not required for this effect. 

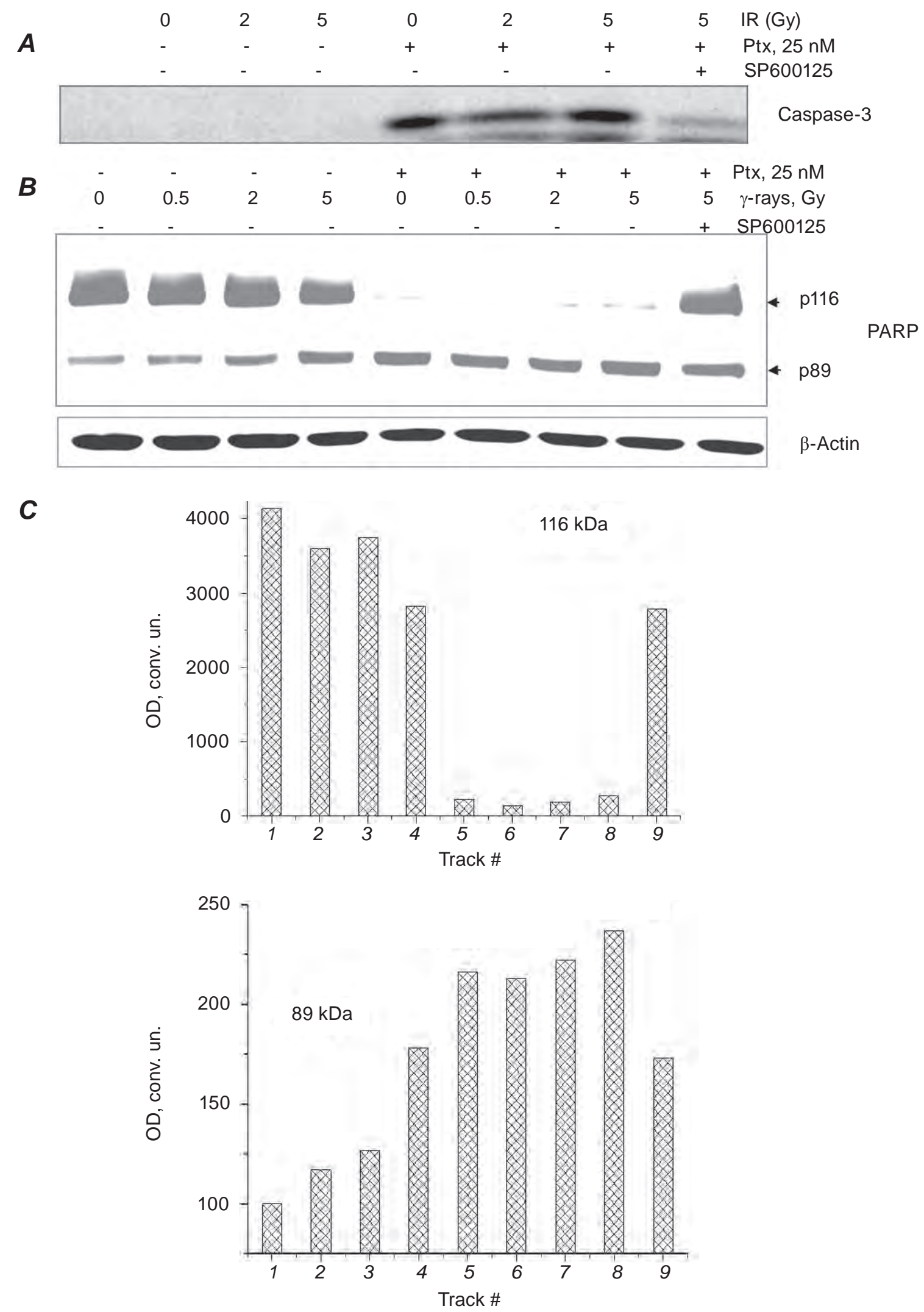

Fig. 4. Effects of Ptx, IR and JNK-inhibitor on caspase-3 activation and PARP cleavage in the KTC-2 cells. $A$ and $B-$ caspase-3 activation and PARP cleavage respectively; $C-$ Quantification of intact PARP (116 kDa) and cleaved PARP (89 kDa fragment). Track \# corresponds to tracks on Fig. 4, B 

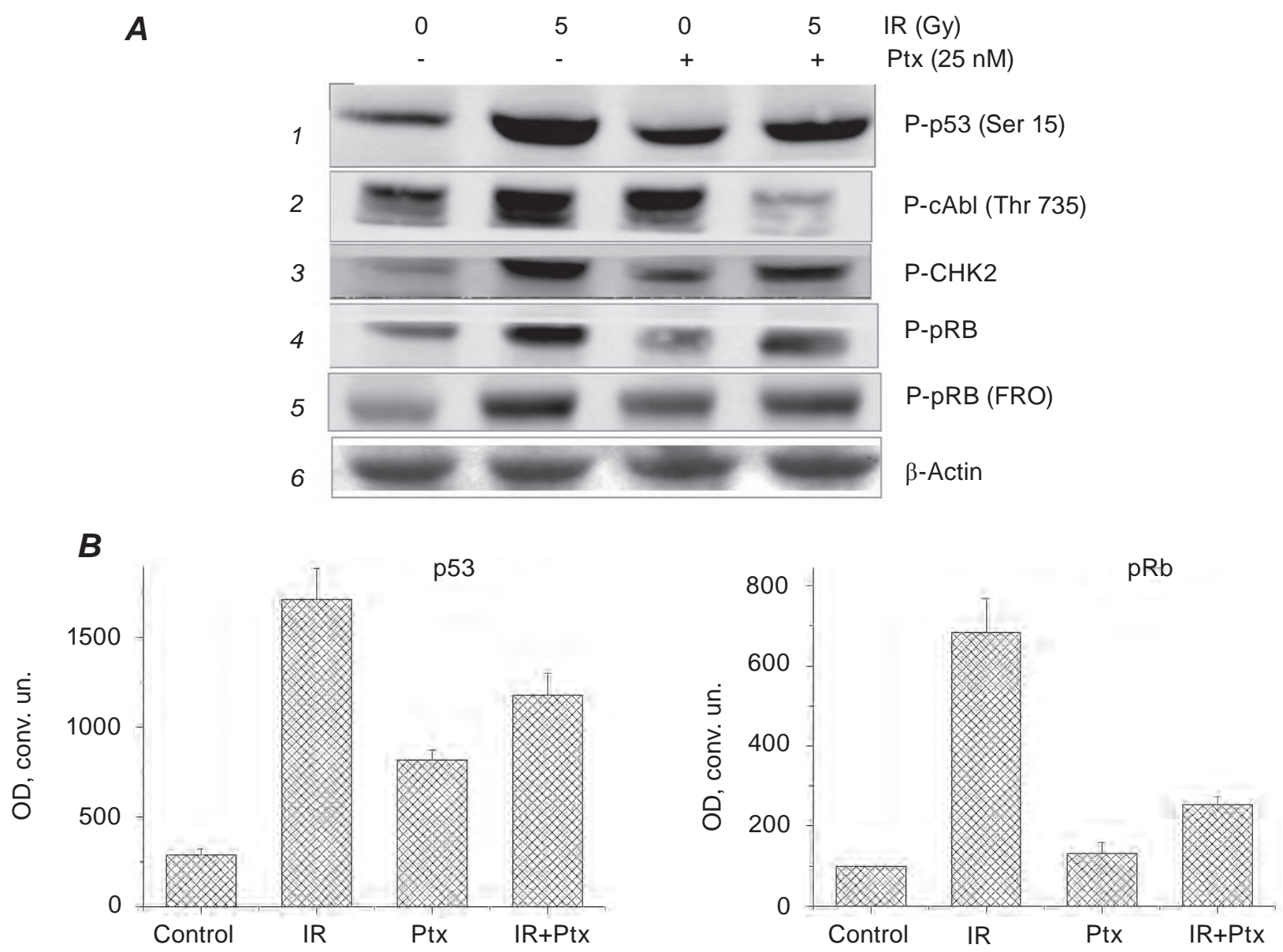

Fig. 5. Effects of Ptx, IR and combined effect of $I R+P t x$ on activation of cell cycle regulators. $A-$ Western blotting study. 1-4 KTC-2, $5-F R O$ cells. $B-Q u a n t i f i c a t i o n$ of some WB results. Data are mean of $4 O D$ measurements of one blot by scanning software $\pm S E$ value

Another possible mechanism of IR-induced apoptosis inhibition by $\mathrm{Bcl}-2$ was detected in endothelial cells [23]. Bcl-2 expression in HDMEC-Bcl-2 cells significantly inhibited irradiation-induced caspase-3 activation that may be due to increased ERK-mediated survivin expression, inhibition of p53 accumulation and p38MAPK activity [23]. Similarly, knockdown of Bcl-2 expression using siRNA augmented Ptx-induced apoptosis in human glioblastoma U138MG and U251MG cells [24].

We have shown previously that Ptx activated CDK1 in ATC cells and this kinase or CDK-related mechanisms but not JNK are mostly responsible for Ptx-dependent Bcl-2 phosphorylation [25]. Perhaps IR additionally enhanced Ptx-induced activation of CDK. This assumption is supported by data which evidenced that activation of CDK is necessary for IR-induced apoptosis [26]. It suggests also that proapoptotic effects of JNK in ATC cells may involve other mechanisms not linked to direct influence upon Bcl-2 family proteins.
Survivin is the protein with complex system of expression regulation, alternative splicing, multiple posttranscriptional and posttranslational modifications. It takes an important part in regulation of cell division and is antiapoptotic factor, which, along with other proteins-inhibitors of apoptosis (IAP), inhibits caspases [27]. There is the evidence that p53 inhibits the expression of survivin [28-30] and this could be the reason for increased survivin level when p53 phosphorylation is suppressed reducing the suppressor amount under the combined action of IR and Ptx. Also Ptx-activated CDK1 [25] could phosphorylate survivin on Thr34 residue and thus to stabilize the protein [27]. Evidently, inhibition of caspases by increased amount of survivin in ATC cells under the combined action of IR and Ptx led to a attenuating of the irradiation effect upon the survival of cells.

Ptx and IR, in particular, induce activation of cell cycle regulatory proteins, which is characteristic of genotoxic stress. Activated p53, c-Abl, CHK2, depending on the strength of external in- 
fluence, determine the direction of cell processes in response to stress. Another important point is the inhibition of their activation under the simultaneous action of Ptx and IR. One can assume that the key factor which determined this inhibition was c-Abl activity. c-Abl - a ubiquitously expressed non-receptor tyrosine kinase, which is activated in response to a variety of signals including the DNA damage and play the important role in IR-induced apoptosis and DNA repair [31, 32]. According to the latest data c-Abl not only stabilizes and activates p53, but is necessary for full activation of upstream transducers ATM and ATR [32], which in turn phosphorylate p53, CHK1, CHK2, BRCA1 and $\mathrm{c}-\mathrm{Abl}$ as well.

It can be assumed that the main reason of the change in proteins activation and expression under the joint action of IR and Ptx is the absence of c-Abl phosphorylation (and activation) which caused in turn the reduction of $\mathrm{CHK} 2$ and p53 activity and, consequently, reduced expression of Bax and increased expression of survivin. It is difficult however to explain such dramatic decrease of c-Abl phosphorylation under combined action of both agents. It is possible that Ptx affects upstream to c-Abl regulatory mechanisms, such as ATM/ ATR activation.

Thus, IR and Ptx are in antagonistic relations regarding phosphorylation and expression of several proteins that mediate the effects of both agents in tumor cells. Perhaps this is due to competition for common signaling cascades that are activated in response to genotoxic stress and to stress related to cytoskeleton structure disturbance. This is indicated by the fact of increased phosphorylation of p53 in the presence of Ptx, which is a typical response to induced by radiation and other genotoxic agents caused the DNA damage. On the other hand, we can suggest that p53 does not play a key role in the mediation of IR- and Ptx-dependent apoptosis, which are confirmed by other data [9].

The antagonism between Ptx and IR in BCap37 (human breast cancer cell line) and KB (human epidermoid carcinoma cell line) cells was observed previously [33]. There was not synergism between IR and Ptx, instead overall cytotoxicity of these agents significantly decreased. In contrast to our data, IR reduced Ptx-induced Bcl-2 phosphorylation in BCap37 and KB cells. The main reason of this antagonism may be cell cycle arrest at G2/M caused by IR [33].

We have shown that the final effect of the interaction of proapoptotic and antiapoptotic factors as well as cell cycle regulators under the combined action of IR and Ptx is a weakening of radiationinduced cell death. Thus, Ptx at certain concentrations (5 $\mathrm{nM}$ in this case) may cause protective effect against IR. This effect may be due to inhibition by Ptx of IR-induced p53 activation. It was shown that p53 inhibitors caused radioprotective effect in mice [34].

The absence of caspases activation and PARP cleavage in ATC cells in $24 \mathrm{~h}$ after irradiation allows assuming that other than apoptosis types of cell death may be initiated. It is also possible that development of apoptotic processes after irradiation needs more prolonged period as compared to Ptx. Data of clonogenic study (Fig. 1, D) and in vivo experiments [3] evidence that it may take up to 2-3 weeks.

\section{БИОХИМИЧЕСКИЕ ЭФФЕКТЫ КОМБИНИРОВАННОГО ВОЗДЕЙСТВИЯ $\gamma$-ОБЛУЧЕНИЯ И ПАКЛИТАКСЕЛА НА КЛЕТКИ АНАПЛАСТИЧЕСКОГО РАКА ЩИТОВИДНОЙ ЖЕЛЕЗЫ}

\section{В. М. Пушкарев, Е. И. Ковзун, В. В. Пушкарев, Н. Д. Тронько}

ГУ «Институт эндокринологии и обмена веществ им. В. П. Комиссаренко НАМН Украины», Киев; e-mail: pushkarev.vm@gmail.com

Целью работы было изучение биохимических эффектов паклитаксела (Ptx), $\gamma$-облучения (IR) и их комбинации в клетках недифференцированного рака щитовидной железы (ATC). IR активирует обычные для повреждения ДНК сигнальные механизмы и проявляет определенный митогенный эффект путем инактивации протеина ретинобластомы $(\mathrm{pRb})$. Наблюдается выраженный антагонизм между Ptx и IR в отношении регуляторов клеточного цикла - опухолевого супрессора р53, $\mathrm{pRb}, \mathrm{CHK} 2$ и c-Abl, а также экспрессии проапоптического протеина Вах, но совместное действие обоих агентов усиливает активацию каспазы-3 и, особенно, каспазы-8. Ptx в низких (1-25 нМ) концентрациях оказывает заметный радиопротекторный эффект.

Таким образом, в клетках АТС наблюдаются конкурентные взаимоотношения между IR и Ptx касательно фосфорилирования протеинов, контролирующих клеточный цикл: p53, pRb, СНК2, сAbl и экспрессии Вах. В то же время, комбинированное действие IR и Ptx усиливает фосфорилирование антиапоптического протеина Bcl-2 и экспрессию ингибитора апоптоза - сурвайвина. Итоговый эффект этих событий можно рассматривать как антиапоптотический - в присутствии Ptx цитотоксичность IR ослабляется. 
К л юч е вы е с лова: паклитаксел, ионизирующая радиация, рак щитовидной железы, апоптоз, клеточный цикл.

\section{БIОХIMIЧНI ЕФЕКТИ \\ КОМБІНОВАНОЇ ДІї \\ $\gamma$-ОПРОМІНЕННЯ ТА ПАКЛІТАКСЕЛУ \\ НА КЛІТИНИ АНАПЛАСТИЧНОГО РАКУ ЩИТОВИДНОЇ ЗАЛОЗИ}

\author{
В. М. Пушкарьов, О. І. Ковзун, \\ В. В. Пушкарьов, М. Д. Тронько
}

\begin{abstract}
ДУ «Інститут ендокринології та обміну речовин ім. В. П. Комісаренка НАМН України», Київ; e-mail: pushkarev.vm@gmail.com
\end{abstract}

Метою роботи було вивчення біохімічних ефектів паклітакселу (Ptx), $\gamma$-опромінення (IR) таїх комбінаціїв клітинахнедиференційованого раку щитовидної залози (ATC). IR активує звичайні за пошкодження ДНК сигнальні механізми і виявляє певний мітогенний ефект шляхом інактивації протеїну ретинобластоми (pRb). Спостерігається виражений антагонізм між Ptx i IR щодо регуляторів клітинного циклу - пухлинного супресора p53, pRb, CHK2 та c-Abl, а також експресії проапоптичного протеїну Вах. Цитотоксичність Ptx є помітно вищою порівняно 3 генотоксичним ефектом IR, але спільна дія обох агентів посилює активацію каспази-3 та, особливо, каспази-8. Ptx в низьких (1-25 нМ) концентраціях спричинює помітний радіопротекторний ефект.

Таким чином, в клітинах АТС спостерігали конкурентні взаємовідношення між IR i Ptx щодо фосфорилювання протеїнів, що контролюють клітинний цикл: p53, pRb, cAbl та експресії Вах. Водночас, комбінований вплив IR i Ptx посилює фосфорилювання антиапоптозного протеїну Bcl-2 та експресію інгібітора апоптозу - сурвайвіну. Підсумковий ефект цих подій можна розглядати як антиапоптотичний - у присутності Ptx цитотоксичність IR послаблюється.

К л ю ч о в і с л о в а: паклітаксел, іонізуюча радіація, рак щитовидної залози, апоптоз, клітинний цикл.

1. Rowinsky E. K. // Ann. Rev. Med. - 1997. 48. - P. 353-374.

2. Kingston D. G. I. // Phytochemistry. - 2007. 68. - P. 1844-1854.

3. Pushkarev V. M., Starenki D. V., Saenko V. O., et al. // Exp. Oncol. - 2011. - 33, N 1. P. 24-27.
4. Freshney R. I. Culture of animal cells, a manual of basic techniques. 5th ed. Hoboken NJ, John Wiley \& Sons, 2005. - 746 p.

5. Henningsson A., Karlsson M. O., Vigano L. // J. Clin. Oncol. - 2001. - 19. - P. 4065-4073.

6. Marchetti P., Urien S., Cappellini G. A. et al. // Crit. Rev. Oncol. Hematol. - 2002. - 44. P. 3-13.

7. Pushkarev V. M., Starenki D. V., Saenko V. A. et al. // Endocrinology. - 2004. - 145. P. 3143-3152.

8. Boldt S., Weidle U. H., Kolch W. // Carcinogenesis. - 2002. - 23. - P. 1831-1838.

9. Levine A. J., Hu W., Feng Z. // Cell Death Differ. - 2006. - 13. - P. 1027-1036.

10. Lalier L., Cartron P.-F., Juin P. et al. // Apoptosis. - 2007. - 12. - P. 887-896.

11. Sionov R. V., Coen S., Goldberg Z. et al. // Mol. Cell. Biol. - 2001. - 21, N 17. - P. 5869-5878.

12. Zuckerman V., Lenos K., Popowicz G. M. et al. // J. Biol. Chem. - 2009. - 284, N 6. P. 4031-4039.

13. Nehme A., Lee B. L., Baskaran R. et al. // Brit. J. Cancer. -2000 . - 83, N 10. - P. 1360-1366.

14. Nevins J. R. // Hum. Mol. Genet. - 2001. 10, N 7. - P. 699-703.

15. Sears R. C., Nevins J. R. // J. Biol. Chem. 2002. - 277, N 14. - P. 11617-11620.

16. Pushkarev V. M., Starenki D. V., Saenko V. A. et al. // Exp. Oncol. - 2008. - 30, N 3. P. 190-194.

17. Pan J., Хu G., Yeung S.-C.J. // J. Clin. Endocrinol. Metab. - 2001. - 86, N 10. P. 4731-4740.

18. Labi V., Grespi F., Baumgartner F. Villunger A. // Cell Death Differ. - 2008. - 15. - P. 977987.

19. Skommera J., Wlodkowic D., Deptala A. // Leukemia Res. - 2007. - 31. - P. 277-286.

20. Geng F., Tang L., Li Y. et al. // J. Biol. Chem. 2011. - 286, N 37. - P. 32259-32267.

21. Zhang L., Blackwell K., Altaeva A. et al. // Mol. Biol. Cell. - 2011. - 22. - P. 128-140.

22. Mu Z., Hachem P., Pollack A. // Prostate. 2005. - 65, N 4. - P. 331-340.

23. Kumar P., Coltas I. K., Kumar B. et al. // Cancer Res. - 2007. - 67. - P. 1193-1202.

24. George J., Banik N. L., Ray S. K. // Neurochem. Res. - 2009. - 34, N 1. - P. 66-78.

25. Pushkarev V. V., Kovzun O. I., Pushkarev V. M., Tronko M. D. // ISRN Biochemistry. - 2012. 2012. - P. 1-6. doi:10.5402/2012/826305.

26. Sohn D., Essmann F., Schulze-Osthoff K. et al. // Cancer Res. - 2006. - 66. - P. 1125411262. 
27. Altieri D. C. // Nat. Rev. Cancer. - 2008. 8. - P. 61-70.

28. Hoffman W. H., Biade S., Zilfou J. T. et al. // J. Biol. Chem. - 2002. - 277, N 5. - P. 32473257.

29. Mirza A., McGuirk M., Hockenberry T. N. et al. // Oncogene. - 2002. - 21. - P. 2613-2622.

30. Raj D., Liu T., Samadashwily G. et al. // Carcinogenesis. - 2008. - 29, N 1. - P. 194-201.
31. Shaul Y., Ben-Yehoyada M. // Cell Res. 2005. - 15, N 1. - P. 33-35.

32. Wang X., Zeng L., Wang J. et al. // Cell Death Differ. - 2011. - 18. - P. 5-15.

33. Sui M., Dziadyk J. M., Zhu X., Fan W. // Clin. Cancer Res. - 2004. - 10. - P. 4848-4857.

34. Strom E., Sathe S., Komarov P. G. et al. // Nature. Chem. Biol. - 2006. - 2, N 9. P. 474-479.

Received 01.03.2012 